\title{
Effects of replacing magnesium oxide with calcium-magnesium carbonate with or without sodium bicarbonate on ruminal fermentation and nutrient flow in vitro
}

\author{
B. C. Agustinho, ${ }^{1 *} \dagger \odot$ A. Ravelo, ${ }^{1} \odot$ J. R. Vinyard, ${ }^{1} \odot$ R. R. Lobo, ${ }^{1} \odot$ J. A. Arce-Cordero, ${ }^{1} \odot$ H. F. Monteiro, ${ }^{1} \ddagger \odot$ \\ E. Sarmikasoglou, ${ }^{1}$ S. Bennett, ${ }^{1} \S \odot$ M. L. Johnson, ${ }^{1}$ E. R. Q. Vieira, ${ }^{1} \# \odot$ C. Stoffel, ${ }^{2} \odot$ S. E. Stocks, ${ }^{2}$ \\ and A. P. Faciola ${ }^{1} \dagger$ () \\ ${ }^{1}$ Department of Animal Sciences, University of Florida, Gainesville 32608 \\ ${ }^{2}$ Papillon Agricultural Company and MIN-AD Inc., Easton, MD 21601
}

\begin{abstract}
The objective of this study was to evaluate the effects of replacing magnesium oxide $(\mathrm{MgO})$ with calcium-magnesium carbonate $\left[\mathrm{CaMg}\left(\mathrm{CO}_{3}\right)_{2}\right]$ on ruminal fermentation with or without the addition of sodium bicarbonate $\left(\mathrm{NaHCO}_{3}\right)$. Eight fermentors of a dualflow continuous-culture system were distributed in a replicated (2) $4 \times 4$ Latin square design in a $2 \times 2$ factorial arrangement of treatments (magnesium sources $\left.\times \mathrm{NaHCO}_{3}\right)$. The treatments tested were $0.21 \% \mathrm{MgO}$ [MgO; dry matter (DM) basis; $144.8 \mathrm{mEq}$ of dietary cation-anion difference (DCAD)]; $0.21 \% \mathrm{MgO}+0.50 \%$ $\mathrm{NaHCO}_{3}\left(\mathrm{MgO}+\mathrm{NaHCO}_{3}\right.$; DM basis; $205.6 \mathrm{mEq}$ of DCAD $) ; 1.00 \% \mathrm{CaMg}\left(\mathrm{CO}_{3}\right)_{2}\left[\mathrm{CaMg}\left(\mathrm{CO}_{3}\right)_{2} ; \mathrm{DM}\right.$ basis; $144.8 \mathrm{mEq}$ of DCAD]; and $1.00 \% \mathrm{CaMg}\left(\mathrm{CO}_{3}\right)_{2}+0.50 \%$ $\mathrm{NaHCO}_{3} \quad\left[\mathrm{CaMg}\left(\mathrm{CO}_{3}\right)_{2}+\mathrm{NaHCO}_{3} ; \quad \mathrm{DM}\right.$ basis; 205.6 $\mathrm{mEq}$ of DCAD]. Diets were formulated to have a total of $0.28 \%$ of $\mathrm{Mg}$ (DM basis). The experiment consisted of $40 \mathrm{~d}$, which was divided into 4 periods of $10 \mathrm{~d}$ each, where $7 \mathrm{~d}$ were used for adaptation and $3 \mathrm{~d}$ for sampling to determine $\mathrm{pH}$, volatile fatty acids (VFA), ammonia $\left(\mathrm{NH}_{3}-\mathrm{N}\right)$, lactate, mineral solubility, $\mathrm{N}$ metabolism, and nutrient digestibility. The effects of $\mathrm{Mg}$ source $[\mathrm{MgO}$ vs. $\left.\mathrm{CaMg}\left(\mathrm{CO}_{3}\right)_{2}\right], \mathrm{NaHCO}_{3}$ (with vs. without), and the interaction were tested with the MIXED procedure of SAS version 9.4 (SAS Institute). There was no $\mathrm{Mg}$
\end{abstract}

Received July 12, 2021.

Accepted December 6, 2021.

*Current address: Department of Animal, Veterinary and Food Sciences, University of Idaho, Moscow 83844.

†Corresponding authors: brunac@uidaho.edu and afaciola@ufl.edu

$\ddagger$ Current address: Department of Population Health and Reproduction, School of Veterinary Medicine, University of California, Davis 95616.

§Current address: Department of Animal Sciences, Pennsylvania State University, University Park 16802.

\#Current address: Department of Animal Sciences, Federal University of Tocantins, Araguaína, TO, Brazil 77020-021. source $\times \mathrm{NaHCO}_{3}$ interaction in the $\mathrm{pH}$ variables and mineral solubility, and $\mathrm{Mg}$ sources evaluated did not affect the variables related to ruminal $\mathrm{pH}$ and solubility of $\mathrm{Mg}$. On the other hand, the inclusion of $\mathrm{NaHCO}_{3}$ increased the $\mathrm{pH}$ daily average, independent of $\mathrm{Mg}$ source, which led to a reduced time that $\mathrm{pH}$ was below 5.8 and decreased area under the curve. Total VFA and lactate concentration were similar among treatments regardless of $\mathrm{NaHCO}_{3}$ and $\mathrm{Mg}$ source; however, the molar proportion of isobutyrate and $\mathrm{NH}_{3}-\mathrm{N}$ concentration were lower in diets with $\mathrm{CaMg}\left(\mathrm{CO}_{3}\right)_{2}$ compared with $\mathrm{MgO}$. Moreover, $\mathrm{NaHCO}_{3}$ inclusion increased $\mathrm{NH}_{3} \mathrm{~N}$, total daily $\mathrm{NH}_{3}-\mathrm{N}$ flow, isobutyrate concentration, and acid detergent fiber digestibility. Our results showed that $\mathrm{CaMg}\left(\mathrm{CO}_{3}\right)_{2}$ leads to a lower $\mathrm{NH}_{3}-\mathrm{N}$ concentration and isobutyrate proportion. Therefore, because most of the tested variables were not significantly different between $\mathrm{MgO}$ and $\mathrm{CaMg}\left(\mathrm{CO}_{3}\right)_{2}$ when combined or not with $\mathrm{NaHCO}_{3}, \mathrm{CaMg}\left(\mathrm{CO}_{3}\right)_{2}$ can be a viable alternative source to replace $\mathrm{MgO}$ in dairy cow diets without affecting mineral solubility, ruminal $\mathrm{pH}$, nutrient digestibility, total VFA, and the main ruminal VFA. Although $\mathrm{Mg}$ sources are known to have an alkalizing effect, $\mathrm{NaHCO}_{3}$ inclusion in diets with $\mathrm{Mg}$ supplementation allowed an increase in ruminal $\mathrm{pH}$, as well as an increase in isobutyrate and $\mathrm{NH}_{3}-\mathrm{N}$ flow.

Key words: macromineral, magnesium oxide, $\mathrm{pH}$, ruminal fermentation

\section{INTRODUCTION}

Magnesium is an essential mineral to the metabolism of dairy cows because it is a cofactor for many vital enzymes. The most used magnesium source in dairy cow diets is magnesium oxide (MgO; NRC, 2001; Goff, 2018). Magnesium oxide has been shown to have alkalizing effects in the rumen (Bach et al., 2018) and to increase milk fat synthesis in dairy cows (Erdman et al., 1980). 
Because $\mathrm{MgO}$ is an expensive $\mathrm{Mg}$ source, other sources, such as calcium-magnesium carbonate $\left[\mathrm{CaMg}\left(\mathrm{CO}_{3}\right)_{2}\right]$ and calcium-magnesium hydroxide $\left[\mathrm{CaMg}(\mathrm{OH})_{4}\right]$, have been studied in relation to ruminal fermentation and dairy cow performance as potential alternatives to $\mathrm{MgO}$ (May et al., 2009; Leno et al., 2017; Arce-Cordero et al., 2020, 2021). Calcium-magnesium carbonate is a potential source for replacing $\mathrm{MgO}$ with no differences in dairy cow performance (Leno et al., 2017) and in vitro ruminal nutrient digestibility (Arce-Cordero et al., 2020).

Magnesium sources also have effects in controlling ruminal $\mathrm{pH}$ because of their alkalizing capacity. Teh et al. (1985) observed that dairy cows in early lactation supplemented with $0.8 \% \mathrm{MgO}$ had a similar $\mathrm{pH}$ of cows supplemented with $\mathrm{NaHCO}_{3}$, which was a greater ruminal $\mathrm{pH}$ than in cows supplemented with $0.4 \%$ of $\mathrm{MgO}$. In addition, Thomas and Emery (1969) observed that cows fed with a roughage-restricted diet, supplemented with $181 \mathrm{~g} / \mathrm{d}$ of $\mathrm{MgO}$, had a greater ruminal $\mathrm{pH}$ than cows fed with $136 \mathrm{~g} / \mathrm{d}$; however, they did not observe additional effects of combining $\mathrm{MgO}$ supplementation with $\mathrm{NaHCO}_{3}$. On the other hand, Erdman et al. (1982), feeding dairy cows in early postpartum combining $0.8 \%$ of $\mathrm{MgO}$ and $1 \%$ of $\mathrm{NaHCO}_{3}$ supplementation, observed that the association of both components had a greater effect in increasing NDF digestibility than either component individually.

In addition to $\mathrm{MgO}$, other $\mathrm{Mg}$ sources have been tested in dairy cow diets, such as calcareous marine. Calcareous marine is similar to $\mathrm{CaMg}\left(\mathrm{CO}_{3}\right)_{2}$, predominantly constituted by $\mathrm{Ca}$ and $\mathrm{Mg}$ (Bernard et al., 2014; Cruywagen et al., 2015; Neville et al., 2019). Cruywagen et al. (2015) and Neville et al. (2019) observed that cows supplemented with calcareous marine had a lower time that rumen $\mathrm{pH}$ was below 5.5 than control diets.

Although some studies test magnesium sources in dairy cows, the effects of combining $\mathrm{CaMg}\left(\mathrm{CO}_{3}\right)_{2}$ with sodium bicarbonate $\left(\mathrm{NaHCO}_{3}\right)$ on ruminal fermentation and nutrient digestibility is still unknown. Therefore, we hypothesized that $\mathrm{CaMg}\left(\mathrm{CO}_{3}\right)_{2}$ can replace $\mathrm{MgO}$ without affecting ruminal $\mathrm{pH}, \mathrm{VFA}$ concentration, and nutrient digestibility. Moreover, we hypothesized that either $\mathrm{Mg}$ source in combination with $\mathrm{NaHCO}_{3}$ would have a similar effect on ruminal fermentation, and $\mathrm{NaHCO}_{3}$ would have the buffer capacity independent of the $\mathrm{Mg}$ source provided in the treatments. The objective of this study was to evaluate the effects of replacing $\mathrm{MgO}$ with $\mathrm{CaMg}\left(\mathrm{CO}_{3}\right)_{2}$ when both sources were supplemented with or without $\mathrm{NaHCO}_{3}$, and the effects of $\mathrm{NaHCO}_{3}$ in diets supplemented with $\mathrm{Mg}$ sources on ruminal $\mathrm{pH}$, ruminal solubility of $\mathrm{Ca}$ and $\mathrm{Mg}, \mathrm{VFA}$, nutrient digestibility, and $\mathrm{N}$ metabolism.

\section{MATERIALS AND METHODS}

\section{Experimental Design and Diets}

All animal procedures were approved by the University of Florida's Institutional Animal Care and Use Committee. Eight fermentors of a dual-flow continuous-culture system were distributed in a replicated $4 \times 4$ Latin square design in a $2 \times 2$ factorial arrangement. One factor was the magnesium source as a conventional source $(\mathrm{MgO})$ versus an alternative source $\left[\mathrm{CaMg}\left(\mathrm{CO}_{3}\right)_{2} ; \mathrm{MIN}-\mathrm{AD}\right.$, Papillon Agricultural Products]; the other factor was the presence or absence of $\mathrm{NaHCO}_{3}$.

The experimental diets (Table 1) were formulated to provide the same concentration of nutrients and to meet the requirements of lactating Holstein cows with $650 \mathrm{~kg}$ of BW, producing $45 \mathrm{~kg}$ of milk per day, with $3.5 \%$ fat, $3.0 \%$ protein, and $4.8 \%$ lactose, according to NRC (2001). The treatments tested were $\mathrm{MgO}(0.21 \% \mathrm{MgO}$; DM basis; $144.8 \mathrm{mEq}$ of DCAD); $\mathbf{M g O}+\mathrm{NaHCO}_{3}\left(0.21 \% \mathrm{MgO}+0.5 \%\right.$ of $\mathrm{NaHCO}_{3}$, DM basis; $205.6 \mathrm{mEq}$ of DCAD); $\mathbf{C a M g}\left(\mathbf{C O}_{3}\right)_{2}[1 \%$ $\mathrm{CaMg}\left(\mathrm{CO}_{3}\right)_{2}$, DM basis; $144.8 \mathrm{mEq}$ of DCAD]; and $\mathrm{CaMg}\left(\mathrm{CO}_{3}\right)_{2}+\mathrm{NaHCO}_{3}\left[1 \% \mathrm{CaMg}\left(\mathrm{CO}_{3}\right)_{2}+0.5 \%\right.$ $\mathrm{NaHCO}_{3}$, DM basis; $205.6 \mathrm{mEq}$ of DCAD].

The $\mathrm{MgO}$ contained $48.3 \% \mathrm{Mg}$ and $2.09 \% \mathrm{Ca}(\mathrm{DM}$ basis), and the $\mathrm{CaMg}\left(\mathrm{CO}_{3}\right)_{2}$ had $12.6 \% \mathrm{Mg}$ and $21.2 \%$ $\mathrm{Ca}$ (DM basis). The diets were formulated to $0.28 \% \mathrm{Mg}$ and $0.67 \% \mathrm{Ca}$ (DM basis); calcitic limestone was used to reach a uniform concentration of $\mathrm{Ca}$ in all diets. The concentrations of $\mathrm{Mg}$ and $\mathrm{NaHCO}_{3}$ in the diets were based on literature recommendations for lactating Holstein dairy cows (NRC, 2001; Hu and Murphy, 2005).

The whole-plant corn silage was collected and dried in a forced-air oven (Heratherm, Thermo Scientific) at $60^{\circ} \mathrm{C}$ for $72 \mathrm{~h}$. Subsequently, corn silage and the other feedstuffs (corn grain, soybean meal, and grass hay) were ground in a Wiley mill (model no. 2; Arthur H. Thomas Co.) to pass a 2-mm screen. Each ingredient was homogenized, and one sample was taken and ground to pass a 1-mm screen to determine the chemical composition.

\section{Dual-Flow Continuous-Culture System}

The experiment was carried out in a dual-flow continuous-culture system similar to that developed by Hoover et al. (1976). This system accurately simulated the ruminal fermentation (Brandao and Faciola, 2019; Brandao et al., 2020) due to constant temperature at $39^{\circ} \mathrm{C}$, agitation at $100 \mathrm{rpm}$, and infusion of $\mathrm{N}_{2}$ gas to keep an anaerobic environment. The artificial saliva was 
formulated according to Weller and Pilgrim (1974), and the infusion rate of $3.0 \mathrm{~mL} / \mathrm{min}$ of artificial saliva was used to allow liquid and solid flow removal. The saliva was constituted of $1.76 \mathrm{~g}$ of $\mathrm{NaHPO}_{4}, 5 \mathrm{~g}$ of $\mathrm{NaHCO}_{3}$, $0.6 \mathrm{~g}$ of $\mathrm{KCl}, 1.6 \mathrm{~g}$ of $\mathrm{KHCO}_{3}$, and $0.2 \mathrm{~g}$ of urea diluted in $1 \mathrm{~L}$ of water. Total passage rate for the system was maintained at $11 \% / \mathrm{h}$ with liquid removed at $5.5 \% / \mathrm{h}$ and solid allowed to flow out at a rate of $5.5 \% / \mathrm{h}$.

\section{Experimental Period and Feed Management}

The experiment consisted of $40 \mathrm{~d}$ and was divided into 4 periods of $10 \mathrm{~d}$ each $(7 \mathrm{~d}$ of adaptation and 3 $\mathrm{d}$ of sampling). On the first day of each period, rumen content was collected from 2 cannulated lactating Holstein cows $2 \mathrm{~h}$ after morning feeding to inoculate the in vitro system. The cannulated dairy cows were previously adapted to a total mixed diet (38\% wholeplant corn silage, $19 \%$ ground corn, $13 \%$ soybean meal, $11 \%$ cottonseed, $9 \%$ citrus pulp, $8.5 \%$ mineral premix, and $1.5 \%$ palmitic acid supplement, on DM basis). The rumen content was squeezed through 4 layers of cheesecloth, stored into prewarmed $\left(39^{\circ} \mathrm{C}\right)$ thermo bottles (Thermo bottle 3.8 L; Coleman Co. Inc.), and immedi- ately transported to the laboratory. The rumen content from those cows were mixed in the proportion 50:50 ( $\mathrm{vol} / \mathrm{vol}$ ), and the mixture was added into prewarmed fermentors $\left(39^{\circ} \mathrm{C}\right)$ until overflow into the solid effluent container.

Each fermentor was fed daily with $106 \mathrm{~g}$ of diet (DM basis), equally divided into 2 feeding times, one at 0800 and the other at $1800 \mathrm{~h}$, and all the ingredients, including the treatments, were already included in the $106 \mathrm{~g}$. On the first $4 \mathrm{~d}$ of each fermentation period, artificial saliva nonenriched with ${ }^{15} \mathrm{~N}$ was used. On the fifth day, this saliva was replaced with an ${ }^{15} \mathrm{~N}$-enriched saliva formulated to contain $0.077 \mathrm{~g}$ of $\left({ }^{15} \mathrm{NH}_{4}\right)_{2} \mathrm{SO}_{4}$ $10.2 \%$ atom excess (Sigma-Aldrich Co.) per liter until the end of the period. Before the morning feeding on $\mathrm{d}$ 5 , each fermentor received a pulse dose of $0.1733 \mathrm{~g}$ of $\left({ }^{15} \mathrm{NH}_{4}\right)_{2} \mathrm{SO}_{4}$. The ${ }^{15} \mathrm{~N}$ was used as a marker to estimate ruminal microbial protein synthesis (Calsamiglia et al., 1996).

\section{Samples and Data Collection}

Background samples of a homogenized combination of liquid and solid effluents from each fermentor and

Table 1. Ingredient and chemical composition of experimental diets

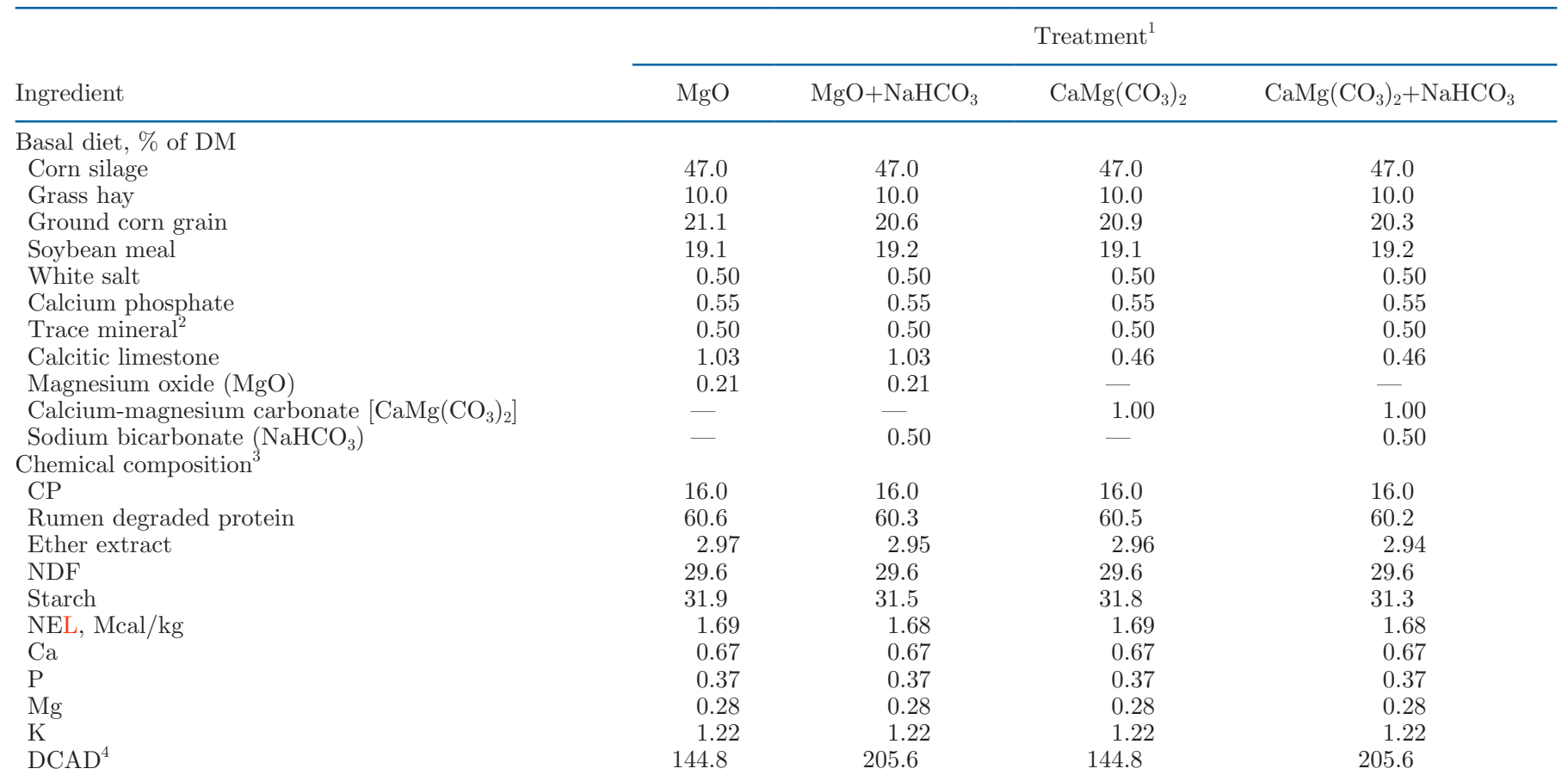

${ }^{1}$ Experimental treatments: $\mathrm{MgO}$ (conventional source of $\mathrm{Mg}$ ); $\mathrm{MgO}+\mathrm{NaHCO}_{3}$ (conventional source of $\mathrm{Mg}$ plus $\mathrm{NaHCO}$ ); $\mathrm{CaMg}_{2}\left(\mathrm{CO}_{3}\right)_{2}($ alternative source of $\mathrm{Mg}$ ); and $\mathrm{CaMg}\left(\mathrm{CO}_{3}\right)_{2}+\mathrm{NaHCO}_{3}$ (alternative source of $\mathrm{Mg}$ plus $\mathrm{NaHCO}_{3}$ ).

${ }^{2}$ Composition on a DM basis: $99 \% \mathrm{NaCl}, 0.35 \% \mathrm{Zn}, 0.2 \% \mathrm{Fe}, 0.2 \% \mathrm{Mn}, 0.03 \% \mathrm{Cu}, 0.007 \% \mathrm{I}$, and $0.005 \% \mathrm{Co}$.

${ }^{3}$ Expressed as a percentage of DM unless otherwise stated.

${ }^{4}$ DCAD: $(\mathrm{Na}+\mathrm{K})-(\mathrm{Cl}+\mathrm{S})$. 
nonenriched artificial saliva sample were collected on d 5 of each period before the application of the ${ }^{15} \mathrm{~N}$ pulse dose to determine DM, ash, and ${ }^{15} \mathrm{~N}$ abundance. Samples were stored at $-20^{\circ} \mathrm{C}$ for later processing.

Ruminal $\mathrm{pH}$ was measured in the fermenters at 0,1 , $2,4,6$, and $8 \mathrm{~h}$ after morning feeding (0800) on d 8 , 9 , and 10 with a portable $\mathrm{pH}$ meter (Thermo Scientific Orion Star A121, Thermo Fisher Scientific Inc.). At each time point, the $\mathrm{pH}$ meter probe was inserted into the fermentors. The $\mathrm{pH}$ data were used to calculate daily average $\mathrm{pH}$, percentage of time below $\mathrm{pH} 5.8$ (HrsB5.8) that was calculated using the threshold of 5.8 , and area under the $\mathrm{pH}$ curve for $\mathrm{pH}$ below 5.8 (AUCB5.8). The area was obtained with the trapezoidal rule (Chiou, 1978). Equations for estimating HrsB5.8 and AUCB5.8 are presented below:

$$
\begin{aligned}
& \text { HrsB5.8 (\%) = } 100 \text { [time below threshold (h/d)/ } \\
& \text { length of daily } \mathrm{pH} \text { monitoring time }(\mathrm{h})] \text {, }
\end{aligned}
$$

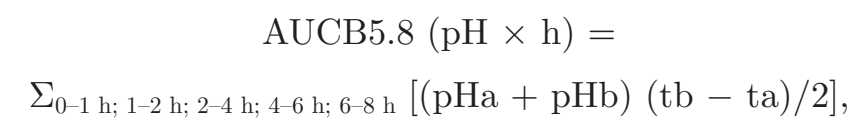

where $\mathrm{pHa}$ and $\mathrm{pHb}$ represent the measured $\mathrm{pH}$ values of each interval between time points at times ta and tb, respectively.

Approximately $10 \mathrm{~mL}$ of samples were collected to determine VFA and $\mathrm{NH}_{3}-\mathrm{N}$, and $1 \mathrm{~mL}$ of samples were collected to determine lactate concentration from inside the fermentors at $0,1,2,4,6$, and $8 \mathrm{~h}$ after morning feeding on $\mathrm{d} 9$ and 10 in each fermentation period. Both samples were manually collected from each vessel, at each time point, using a 25-mL serological pipette (Falcon pipette, Corning Inc.) and filtered through 4 layers of cheesecloth. Samples for VFA and $\mathrm{NH}_{3}-\mathrm{N}$ were acidified with 50\% sulfuric acid at the proportion 99:1 (vol/vol, sample:sulfuric acid) and stored at $-20^{\circ} \mathrm{C}$.

Digesta effluent containers, which consisted of 2 separated containers, one for liquid and another for solid, were immersed in chilled water (around $1^{\circ} \mathrm{C}$ ) on $\mathrm{d}$ 9 and 10 . The daily contents from the liquid and solid containers were pooled for each fermentor and stored at $-20^{\circ} \mathrm{C}$. Also, $210-\mathrm{mL}$ samples from the pooled effluents (mixed of solid and liquid) were collected and filtered through 4 layers of cheesecloth to determine the solubilization of $\mathrm{Mg}$ and $\mathrm{Ca}$ and the production of VFA, $\mathrm{NH}_{3}-\mathrm{N}$, and lactate by fermentation. Samples to determine VFA and $\mathrm{NH}_{3}-\mathrm{N}$ concentration were acidified with 50\% sulfuric acid at the proportion 99:1 (vol/ vol, sample:sulfuric acid) and stored at $-20^{\circ} \mathrm{C}$.

At the end of $\mathrm{d} 10$ of each period, the entire content from each fermentor was blended for $30 \mathrm{~s}$ with $300 \mathrm{~mL}$ of $0.9 \%$ saline solution, squeezed through 4 layers of cheesecloth, and rinsed with $100 \mathrm{~mL}$ of $0.9 \%$ saline solution for isolation of bacteria according to Krizsan et al. (2010). The filtrate was centrifuged (Allegra X15R Centrifuge, Beckman Coulter Life Sciences) at $1,000 \times \mathrm{g}$ for $10 \mathrm{~min}$ at $4^{\circ} \mathrm{C}$ to remove the residual particles from the feed. The supernatant was collected and centrifugated in an ultra-speed centrifuge (Sorvall RC-5B Refrigerated Superspeed Centrifuge, DuPont Instruments) at $11,250 \times g$ for $20 \mathrm{~min}$ at $4^{\circ} \mathrm{C}$ to obtain the bacteria pellet. The pellet was resuspended using $200 \mathrm{~mL}$ of McDougall's solution and centrifuged at $16,250 \times g$ for $20 \mathrm{~min}$ at $4^{\circ} \mathrm{C}$. The bacterial pellet was harvested from the third centrifugation and stored at $-20^{\circ} \mathrm{C}$.

Background, saliva, bacteria pellet, and digesta samples were subsequently dried in a freeze dryer, and their chemical composition was determined to estimate the microbial protein synthesis and ruminal disappearance of nutrient fractions.

\section{Laboratory Analysis}

Rumen fluid samples to determine VFA and $\mathrm{NH}_{3}-\mathrm{N}$ concentration were centrifuged at 10,000 $\times g$ for 15 min at $4^{\circ} \mathrm{C}$. Ammonia nitrogen concentration was determined as described by Broderick and Kang (1980) and adapted to a plate reader by using $2 \mu \mathrm{L}$ of the sample, $100 \mu \mathrm{L}$ of phenol, and $80 \mu \mathrm{L}$ of hypochlorite in each well of the microplate. Absorbance was measured in a spectrophotometer (SpectraMax Plus 384 Microplate Reader, Molecular Devices) at $620 \mathrm{~nm}$.

Samples to determine VFA were processed in a second centrifugation step, according to Ruiz-Moreno et al. (2015), where crotonic and metaphosphoric acid solution was added in a 1:5 ratio to the supernatant and frozen overnight. The sample was then centrifuged at $10,000 \times g$ for $15 \mathrm{~min}$ at $4^{\circ} \mathrm{C}$. The supernatant was recovered, and ethyl acetate was added in a 2:1 ratio to the supernatant, vortexed, and allowed to separate into layers, according to Ruiz-Moreno et al. (2015) with the following modifications. The top layer was transferred to a chromatography vial. The concentration of acetate, propionate, butyrate, isobutyrate, isovalerate, valerate, and caproate was determined by gas chromatography (Agilent 7820A GC, Agilent Technologies) using a flame ionization detector and a capillary column (CP-WAX 58 FFAP $25 \mathrm{~m} 0.53 \mathrm{~mm}$, Varian CP7767, Varian Analytical Instruments) at $110^{\circ} \mathrm{C}$ with injector temperature at $200^{\circ} \mathrm{C}$ and detector at $220^{\circ} \mathrm{C}$.

Lactate concentration was determined using a commercial kit (D-Lactic acid / L-Lactic acid kit, R- 
Biopharm AG). Samples were processed and analyzed according to the instructions provided by the manufacturer. Absorbance was measured in a spectrophotometer (SpectraMax Plus 384 Microplate Reader, Molecular Devices).

Samples to determine $\mathrm{Ca}$ and $\mathrm{Mg}$ solubility were centrifuged at $18^{\circ} \mathrm{C}$ and $2,700 \times g$ for $15 \mathrm{~min}$, and the supernatant was transferred to another tube and centrifuged at $20^{\circ} \mathrm{C}$ and $30,000 \times g$ for $30 \mathrm{~min}$ in an ultra-speed centrifuge (Sorvall RC-5B Refrigerated Superspeed Centrifuge, DuPont Instruments). The supernatant was harvested and stored at $-20^{\circ} \mathrm{C}$. The concentration of soluble $\mathrm{Mg}$ and $\mathrm{Ca}$ was determined in the effluent samples by inductively coupled plasma mass spectrometry, according to method no. 985.01 (AOAC International, 2000).

Saliva, background, digesta, and bacteria samples were placed into 2-mL microcentrifuge tubes using 2.0-mm zirconia beads and sequentially processed in a homogenizer (Precellys 24, Bertin) at 5,500 $\times g$ for 10 $\mathrm{s}$ to process the samples for determination of $\mathrm{N}$ and ${ }^{15} \mathrm{~N}$ percent. The samples were loaded into tin capsules (Elemental microanalysis) and weighed using a microscale (Excellence Plus XP Micro Balance Mettler-Toledo GmbH, Laboratory \& Weighing Technologies). To avoid $\mathrm{NH}_{3}-\mathrm{N}$ contamination during the analysis, $35 \mu \mathrm{L}$ of $\mathrm{K}_{2} \mathrm{CO}_{3}$ solution $(10 \mathrm{~g} / \mathrm{L})$ was added to the samples and allowed to dry overnight in a forced-air oven at $40^{\circ} \mathrm{C}$. The percent ${ }^{15} \mathrm{~N}$ in dried samples was determined using a mass spectrometer (IsoPrime 100, IsoPrime), and the results were expressed as the fractional abundance of isotopic fractions $\left({ }^{15} \mathrm{~N} /{ }^{14} \mathrm{~N}\right)$.

The DM content was determined at $105^{\circ} \mathrm{C}$ using an oven according to method no. 930.15 (AOAC, 1990). Ash was determined by combustion at $600^{\circ} \mathrm{C}$ for $6 \mathrm{~h}$ in a furnace, according to method no. 942.05 (AOAC, 1990). Neutral detergent fiber was determined, according to Mertens et al. (2002), using thermostable $\alpha$-amylase and sodium modified for an Ankom200 Fiber Analyzer (Ankom Technology).

\section{Calculations for N Metabolism and Disappearance of Nutrients}

Total $\mathrm{N}$ present in digesta effluent corresponds to the $\mathrm{N}$ remaining from microbial ruminal fermentation, and it was subdivided into $\mathrm{NH}_{3}-\mathrm{N}$ flow, dietary $\mathrm{N}$ flow, and bacterial $\mathrm{N}$ flow. The NAN is a combination of dietary $\mathrm{N}$ flow and bacterial $\mathrm{N}$ flow.

Flows of $\mathrm{NH}_{3}-\mathrm{N}$, NAN, and bacterial $\mathrm{N}$ were determined according to Calsamiglia et al. (1996) and Bach and Stern (1999) using the following equations:

$$
\begin{aligned}
& \mathrm{NH}_{3}-\mathrm{N} \text { flow }(\mathrm{g} / \mathrm{d})=\mathrm{mg} / \mathrm{dL} \text { of effluent } \mathrm{NH}_{3}-\mathrm{N} \\
& \times(\mathrm{g} \text { of total effluent flow } / 100) ; \\
& \text { NAN flow }(\mathrm{g} / \mathrm{d})= \\
& \mathrm{g} \text { of total } \mathrm{N} \text { in effluent }-\mathrm{g} \text { of effluent } \mathrm{NH}_{3}-\mathrm{N} ;
\end{aligned}
$$

$$
\text { Bacterial } \mathrm{N} \text { flow }(\mathrm{g} / \mathrm{d})=
$$

(NAN flow $\times \%$ atom excess of ${ }^{15} \mathrm{~N}$ in NAN effluent)/

(\% atom excess of ${ }^{15} \mathrm{~N}$ in bacteria pellet),

where $\%$ atom excess of ${ }^{15} \mathrm{~N}$ in NAN effluent $=\%$ atom ${ }^{15} \mathrm{~N}$ in NAN effluent sample $-\%$ atom ${ }^{15} \mathrm{~N}$ in background. In addition, the flow of dietary $\mathrm{N}$ and microbial efficiency indicators were determined according to Bach and Stern (1999) as follows:

$$
\text { Dietary } \mathrm{N} \text { flow }(\mathrm{g} / \mathrm{d})=
$$

$\mathrm{g}$ of NAN in effluent $-\mathrm{g}$ of bacterial $\mathrm{N}$ in effluent;

$$
\text { Bacterial efficiency }=
$$

bacterial $\mathrm{N}$ flow (g)/OM truly digested (kg);

$$
\text { Efficiency of } \mathrm{N} \text { use }=
$$

$($ g of bacterial N/g of available N) $\times 100$.

Ruminal disappearance of the nutrients in the digesta effluent was estimated according to Soder et al. (2013) as follows:

\section{$\%$ Nutrient disappearance $(\mathrm{DM}$ basis $)=$}

$100 \times$ [g of nutrient intake $-(\mathrm{g}$ of nutrient in effluent $-\mathrm{g}$ of nutrient in saliva $-\mathrm{g}$ of nutrient in bacteria)]/

$$
\mathrm{g} \text { of nutrient intake. }
$$

\section{Statistical Analysis}

Data were analyzed with the MIXED procedure of SAS 9.4 (SAS Institute Inc.) as a replicated $4 \times$ 4 Latin square in a $2 \times 2$ factorial arrangement. The model included fermentors as the experimental unit; treatments as a fixed effect; and square, period, and fermentor within square as random effects for average daily $\mathrm{pH}$, nutrient disappearance, $\mathrm{N}$ metabolism, and daily average concentrations of VFA, Ca, and $\mathrm{Mg}$ solubility. For $\mathrm{pH}, \mathrm{NH}_{3}-\mathrm{N}, \mathrm{VFA}$, and lactate kinetics, time was included in the model, and data were analyzed as a repeated measure, and first-order autoregressive was 
adopted as the covariance structure based on Akaike information criterion. The minimal detectable difference was calculated for all the variables. The effects of $\mathrm{Mg}$ source $\left[\mathrm{MgO}\right.$ vs. $\left.\mathrm{CaMg}\left(\mathrm{CO}_{3}\right)_{2}\right], \mathrm{NaHCO}_{3}$ (presence vs. absence), and the interaction between those factors were analyzed by orthogonal contrasts. Significance was declared at $P \leq 0.05$, and tendency was declared at $0.05<P \leq 0.10$.

\section{RESULTS AND DISCUSSION}

\section{Ruminal $\mathrm{pH}$}

There was no detectable $\mathrm{Mg}$ source $\times \mathrm{NaHCO}_{3}$ interaction for ruminal $\mathrm{pH}, \mathrm{pH}$ variables, or mineral solubility $(P>0.17$, Table 2$)$. The absence of detectable differences indicated that $\mathrm{NaHCO}_{3}$ could be used with either $\mathrm{MgO}$ or $\mathrm{CaMg}\left(\mathrm{CO}_{3}\right)_{2}$, and the sources of $\mathrm{Mg}$ tested in this experiment would not change the effect of $\mathrm{NaHCO}_{3}$ on ruminal $\mathrm{pH}$. The results also indicated that mineral solubility was independent of $\mathrm{NaHCO}_{3}$ utilization. When looking at individual factors, there was no detectable difference of $\mathrm{Mg}$ source in the variables related to ruminal $\mathrm{pH}(P>0.31)$.

Components that can modulate ruminal $\mathrm{pH}$ have been tested over the years to mitigate rumen acidosis in high-producing dairy cow diets (Krause and Oetzel, 2006) when substrates are fermented by ruminal microorganisms to VFA and lactate (Van Soest, 1994), consequently leading to a low pH (Owens et al., 1998). Magnesium oxide can be used to aid in the prevention of ruminal $\mathrm{pH}$ reduction in dairy cows (Erdman et al., 1982). In the current study, both $\mathrm{MgO}$ and $\mathrm{CaMg}\left(\mathrm{CO}_{3}\right)_{2}$ had similar effects on ruminal $\mathrm{pH}$, which indicated that $\mathrm{CaMg}\left(\mathrm{CO}_{3}\right)_{2}$ could provide a similar alkalizing effect as $\mathrm{MgO}$. Bach et al. (2018) observed that the supplementation of $\mathrm{MgO}(0.4 \%$ of $\mathrm{DM})$ in diets of dairy cows with an inclusion of $3 \mathrm{~kg} / \mathrm{d}$ of barley to challenge ruminal $\mathrm{pH}$ was able to prevent the reduction of ruminal $\mathrm{pH}$ and decrease the time that $\mathrm{pH}$ was below 5.8, compared with the control treatment and treatment with $\mathrm{NaHCO}_{3}$ inclusion $(0.8 \%$ of DM).

Other mineral sources such as calcareous marine have been tested in dairy cow diets that provide minerals and, at the same time, modulate ruminal $\mathrm{pH}$ and may affect animal performance (Bernard et al., 2014; Cruywagen et al., 2015; Neville et al., 2019). Neville et al. (2019) evaluated the supplementation of calcareous marine with or without marine $\mathrm{MgO}$ versus sodium bicarbonate in mid-lactation dairy cows. Neville et al. (2019) observed that ruminal pH was generally higher, and the time that $\mathrm{pH}$ was below or equal to 5.5 was lower in animals supplemented with calcareous marine combined or not with marine $\mathrm{MgO}$ than the negative

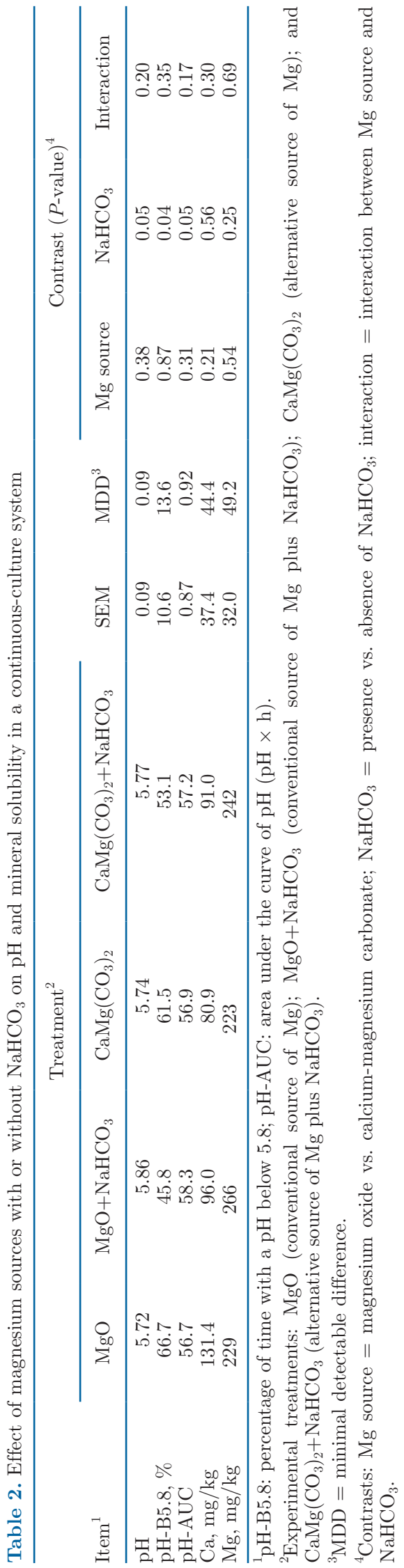


control and sodium bicarbonate. In addition, Cruywagen et al. (2015) observed that calcareous marine had a greater capacity in buffering the rumen than sodium bicarbonate, although sodium bicarbonate already provided a lower time of $\mathrm{pH}$ below 5.5 than the control treatment. In our study, we did not evaluate the effect of $\mathrm{CaMg}\left(\mathrm{CO}_{3}\right)_{2}$ in the rumen against a negative control; however, ruminal fermentation was not affected by $\mathrm{CaMg}\left(\mathrm{CO}_{3}\right)_{2}$ differently than $\mathrm{MgO}$ that is usually associated with alkalizing capacity (Erdman et al., 1982; Bach et al., 2018).

As previously mentioned, nutritionists usually combine $\mathrm{NaHCO}_{3}$ with $\mathrm{MgO}$ in high-producing dairy cow diets to improve the control of ruminal pH (Goff, 2018). The justification of using feed additives to control ruminal $\mathrm{pH}$ is that those diets are formulated to contain a high concentration of grains to meet energy requirements (Krause and Oetzel, 2006), and this condition favors the occurrence of ruminal acidosis (Owens et al., 1998). In the current study, we observed that $\mathrm{NaHCO}_{3}$ provided support for buffer capacity during ruminal fermentation independent of supplemental $\mathrm{Mg}$ source. The inclusion of $\mathrm{NaHCO}_{3}$ increased the average daily $\mathrm{pH}(P=0.05$, Table 2$)$ and consequently led to a lower percentage of time $(P=0.04)$ that $\mathrm{pH}$ was below 5.8 and decreased the area under $\mathrm{pH}$ curve $(P=0.05)$. Although we did not evaluate the alkalizing capacity of $\mathrm{Mg}$ individually, compared with a diet without magnesium, we observed that $\mathrm{NaHCO}_{3}$ was able to play a role as a rumen buffer regardless of which $\mathrm{Mg}$ source was provided in the treatments. The results corroborate the observations of Rogers et al. (1982), where adding $\mathrm{NaHCO}_{3}$ to dairy cow diets increased ruminal $\mathrm{pH}$ and improved nutrient utilization in the rumen. In addition, $\mathrm{Hu}$ and Murphy (2005) observed that ruminal $\mathrm{pH}$ of dairy cows fed corn silage as the main source of forage was greater when supplemented with $\mathrm{NaHCO}_{3}$.

\section{Mineral Solubility}

The results also indicated that mineral solubility was independent of $\mathrm{NaHCO}_{3}$ supplementation. When looking at individual factors, there were no detectable differences of $\mathrm{Mg}$ source in $\mathrm{Mg}(P=0.54)$ and $\mathrm{Ca}(P$ $=0.21)$ solubility in the rumen. Also, there was no detectable difference of buffer in $\mathrm{Mg}$ and Ca solubility $(P=0.25 ; P=0.56$, respectively). The $\mathrm{Mg}$ solubility results observed in this study corroborate the results reported by Zyzak et al. (2002), which observed similar solubility for $\mathrm{MgO}$ and $\mathrm{CaMg}\left(\mathrm{CO}_{3}\right)_{2}$ at acidic $\mathrm{pH}$. The similarity in $\mathrm{Mg}$ solubility is another relevant point that would suggest that it is possible to replace conventional $\mathrm{MgO}$ source with $\mathrm{CaMg}\left(\mathrm{CO}_{3}\right)_{2}$ when availability and prices are comparable. In addition, Arce-Cordero et al. (2020) also observed that $\mathrm{MgO}, \mathrm{CaMg}\left(\mathrm{CO}_{3}\right)_{2}$, and $\mathrm{CaMg}(\mathrm{OH})_{4}$ had similar mineral solubility in vitro. However, Arce-Cordero et al. (2020) did not evaluate if $\mathrm{CaMg}\left(\mathrm{CO}_{3}\right)_{2}$ or $\mathrm{MgO}$ combined with $\mathrm{NaHCO}_{3}$ would still provide similar mineral solubility independent of the source because the only source that they combined with buffer (sodium sesquicarbonate) was $\mathrm{MgO}$.

In our study, we observed that $\mathrm{CaMg}\left(\mathrm{CO}_{3}\right)_{2}$ could also be combined with $\mathrm{NaHCO}_{3}$ without affecting mineral solubility. Arce-Cordero et al. (2021) also evaluated the replacement of $\mathrm{MgO}$ with a blend of $\mathrm{CaMg}\left(\mathrm{CO}_{3}\right)_{2}$ and $\mathrm{CaMg}(\mathrm{OH})_{4}$, and they observed that $\mathrm{MgO}$ had a greater $\mathrm{Mg}$ solubility compared with the blend that is possibly related to $\mathrm{CaMg}(\mathrm{OH})_{4}$ solubility or other factors such as particle size and $\mathrm{Mg}$ source. According to Beede (2017), mineral solubility may be affected by mineral sources; however, the calcination process, particle size, and contamination with other minerals can have a strong effect on the solubility of calcined sources such as $\mathrm{MgO}$. These factors affecting solubility may explain the lack of consistency in previous studies with the same mineral source. In addition, Zyzak et al. (2002) observed that apparent absorption and retention of $\mathrm{Mg}$ in sheep did not differ between $\mathrm{CaMg}\left(\mathrm{CO}_{3}\right)_{2}$ and $\mathrm{MgO}$, which indicates that not only the solubility was not affected by those sources, but also the metabolism was not different between sources. Therefore, in the current study, mineral solubility was similar between $\mathrm{MgO}$ and $\mathrm{CaMg}\left(\mathrm{CO}_{3}\right)_{2}$. Although Bernard et al. (2014) did not evaluate ruminal mineral solubility, they observed that early-lactation dairy cows supplemented with calcareous marine (a source that also provides $\mathrm{Ca}$ and $\mathrm{Mg}$ ) against sodium bicarbonate and a negative control did not have differences in the blood mineral concentration. Although there was no statistical difference, we speculate that Ca solubility was numerical greater in the diets formulated with $\mathrm{MgO}$ because of the greater Ca solubility from calcitic limestone, which was used to adjust the $\mathrm{Ca}$ concentration in the diets, compared with $\mathrm{CaMg}\left(\mathrm{CO}_{3}\right)_{2}$.

\section{Volatility Fatty Acids, Lactate, and N Metabolism}

There was no treatment $\times$ time interaction for the repeated measures of VFA, lactate, and $\mathrm{NH}_{3}-\mathrm{N}$ (data not shown). This indicated that, although there was an effect of time for those variables, the variation pattern was similar among the treatments over time. The effects of $\mathrm{Mg}$ source $\times \mathrm{NaHCO}_{3}$ interaction and individual effects of $\mathrm{Mg}$ source and $\mathrm{NaHCO}_{3}$ inclusion on VFA molar proportion and $\mathrm{N}$ metabolism parameters are presented in Tables 3 and 4, respectively. There was no $\mathrm{Mg}$ source $\times \mathrm{NaHCO}_{3}$ interaction for VFA proportion $(P>0.13)$, total VFA concentration $(P=0.14)$, 


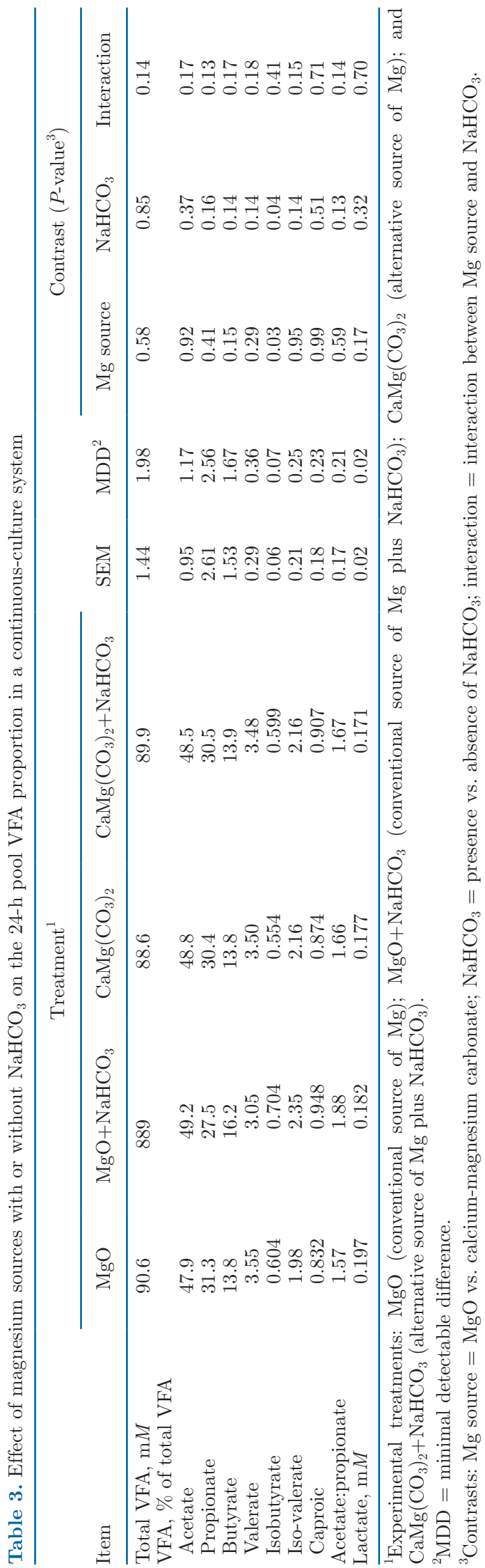

or lactate concentration $(P=0.70)$. Also, the total VFA and lactate concentration was similar between $\mathrm{Mg}$ sources $(P=0.58 ; 0.17)$, and $\mathrm{NaHCO}_{3}$ inclusion $(P=$ $0.85 ; 0.32)$; however, the molar proportion of isobutyrate was lower in diets with $\mathrm{CaMg}\left(\mathrm{CO}_{3}\right)_{2}$ compared with $\mathrm{MgO}(P=0.03)$.

Isobutyrate is a branched-chain VFA associated with AA degradation in the rumen (Dehority et al., 1958). The difference in isobutyrate molar proportion was associated with $\mathrm{NH}_{3}-\mathrm{N}$ concentration, which was also lower in the diets with $\mathrm{CaMg}\left(\mathrm{CO}_{3}\right)_{2}$ supplementation $(P<0.01$, Table 4$)$, indicating a possible effect on protein degradation. The reduction in $\mathrm{NH}_{3}-\mathrm{N}$ concentration also led to a reduction in the total flow of $\mathrm{NH}_{3}-\mathrm{N}$ $(P<0.01)$.

On the other hand, $\mathrm{NaHCO}_{3}$ inclusion evaluated individually increased $\mathrm{NH}_{3}-\mathrm{N}(P=0.01)$, leading to an increase in the total daily $\mathrm{NH}_{3}$ - N flow $(P=0.02)$. Lana et al. (1998) observed a correlation between ruminal $\mathrm{pH}$ and deamination, and the increase in ruminal $\mathrm{pH}$ could have favored deamination and consequently increased $\mathrm{NH}_{3}-\mathrm{N}$ concentration when $\mathrm{NaHCO}_{3}$ was included in the diets. This increased deamination may explain the increase in isobutyrate molar proportion $(P=0.04)$ because this VFA comes from valine metabolism during rumen fermentation (Dehority et al., 1958). Future investigations are required to better understand the mechanism related to $\mathrm{MgO}$ that affects $\mathrm{NH}_{3}-\mathrm{N}$ concentration and, consequently, isobutyrate molar proportion. A tendency for $\mathrm{Mg}$ source $\times \mathrm{NaH}-$ $\mathrm{CO}_{3}$ interaction was observed in RDP concentration $(P=0.10)$, in which the treatment with $\mathrm{MgO}$ plus $\mathrm{NaHCO}_{3}$ had a greater RDP than the treatment with just $\mathrm{MgO}$ supplementation; however, $\mathrm{CP}$ digestibility was similar between treatments $(P>0.19)$. There was no $\mathrm{Mg}$ source $\times \mathrm{NaHCO}_{3}$ interaction, neither for the main effect of $\mathrm{Mg}$ source nor $\mathrm{NaHCO}_{3}$ inclusion on any other variables related to $\mathrm{N}$ metabolism $(P>0.39, P=$ $0.27, P=0.48$, respectively). This indicated that both $\mathrm{MgO}$ and $\mathrm{CaMg}\left(\mathrm{CO}_{3}\right)_{2}$, at the tested concentrations, had similar effects on $\mathrm{N}$ utilization.

There was no effect of $\mathrm{NaHCO}_{3}$ on this acetate: propionate ratio in the current study where all the diets had $\mathrm{Mg}$ supplementation $(P=0.13)$. Moreover, the other VFA proportions were not affected by $\mathrm{Mg}$ source or $\mathrm{NaHCO}_{3}$ inclusion $(P>0.15 ; 0.13)$, and neither was the ratio of acetate:propionate affected by $\mathrm{Mg}$ source $(P=0.59)$.

\section{Dry Matter and Nutrient Digestibility}

There was no $\mathrm{Mg}$ source $\times \mathrm{NaHCO}_{3}$ interaction for DM and nutrient digestibility (Table $5 ; P>0.25$ ). Also, when looking at individual factors, there was no 







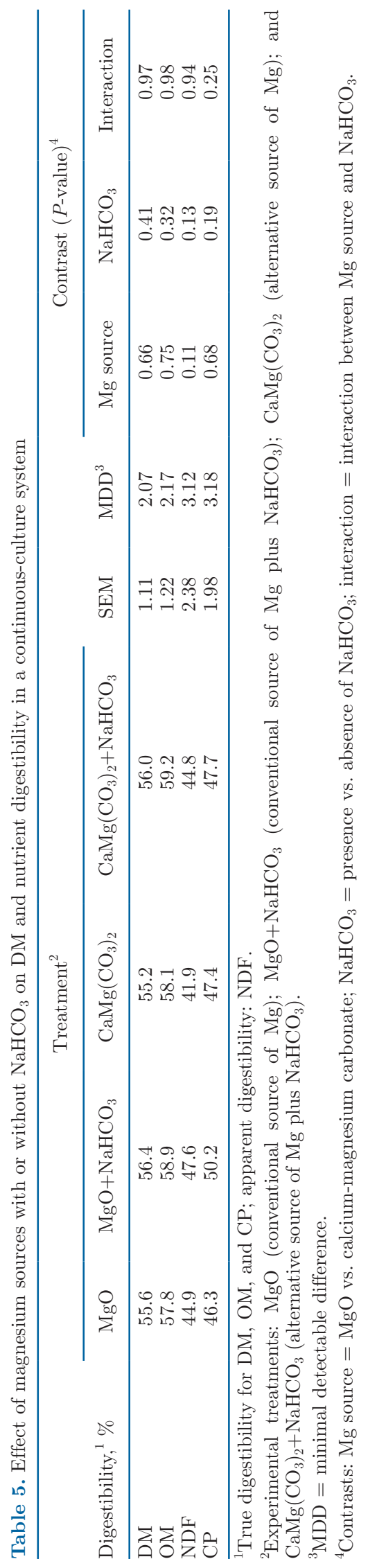

detectable difference between $\mathrm{Mg}$ source or $\mathrm{NaHCO}_{3}$ on DM and nutrient digestibility $(P>0.11$ and 0.13 , respectively). Different than that observed in the present study, Arce-Cordero et al. (2021) observed an interaction $\mathrm{Mg}$ source $\times \mathrm{NaHCO}_{3}$ in which the buffer increased the $\mathrm{CP}$ digestibility only when the diet was supplemented with $\mathrm{MgO}$. Although $\mathrm{NaHCO}_{3}$ inclusion did not affect NDF digestibility in the present study, the literature reports the opposite when buffers are added to the diets with $\mathrm{Mg}$ supplementation. Rogers et al. (1982) observed that adding $2 \% \mathrm{NaHCO}_{3}$ (DM basis) in dairy cow diets increased fiber digestibility. Also, an increase in fiber digestibility was observed by Erdman et al. (1980) in diets with $1 \% \mathrm{NaHCO}_{3}$ inclusion compared with control treatment. In addition, Arce-Cordero et al. (2021) also did not observe effects of $\mathrm{Mg}$ sources in DM and NDF when using a dual-flow continuous-culture system; however, they observed a buffer effect on NDF digestibility.

\section{CONCLUSIONS}

We found that $\mathrm{CaMg}\left(\mathrm{CO}_{3}\right)_{2}$ reduced $\mathrm{NH}_{3}-\mathrm{N}$ concentration and isobutyrate and had no differences in regards to digestibility and ruminal fermentation when compared with $\mathrm{MgO}$. This allows for the use of $\mathrm{CaMg}\left(\mathrm{CO}_{3}\right)_{2}$ as a feasible alternative source of $\mathrm{Mg}$ in dairy cow diets without affecting mineral solubility, ruminal $\mathrm{pH}$, and nutrient digestibility. In addition, combining $\mathrm{CaMg}\left(\mathrm{CO}_{3}\right)_{2}$ with $\mathrm{NaHCO}_{3}$ can control ruminal $\mathrm{pH}$ and improve $\mathrm{N}$ metabolism. Although $\mathrm{Mg}$ sources are known to have an alkalizing effect, $\mathrm{NaHCO}_{3}$ inclusion in diets with $\mathrm{Mg}$ supplementation increased ruminal $\mathrm{pH}$, as well as isobutyrate and $\mathrm{NH}_{3}-\mathrm{N}$ flow.

\section{ACKNOWLEDGMENTS}

The authors acknowledge Papillon Agricultural Company Inc. and MIN-AD Inc. (Easton, MD) for partial financial support of this project. The authors also thank the Brazilian Research Council (CNPq; Brasilia, Brazil) for the scholarship granted to the first author (B. C. A.) during the $\mathrm{PhD}$ program, and William Price (University of Idaho, Moscow) for statistical support. The authors have not stated any conflicts of interest.

\section{REFERENCES}

AOAC. 1990. Official Methods of Analysis. 15th ed. Association of Official Agricultural Chemists.

AOAC International. 2000. Official Methods of Analysis. 17th ed. AOAC International.

Arce-Cordero, J. A., H. F. Monteiro, V. L. N. Brandao, X. Dai, S. L. Bennett, and A. P. Faciola. 2020. Effects of calcium-magnesium carbonate and calcium-magnesium hydroxide as supplemental 
sources of magnesium on microbial fermentation in a dual-flow continuous culture. Transl. Anim. Sci. 5:txa229. https://doi.org/ $10.1093 /$ tas $/$ txaa229.

Arce-Cordero, J. A., A. Ravelo, J. R. Vinyard, H. F. Monteiro, B. C. Agustinho, E. Sarmikasoglou, S. L. Bennet, and A. P. Faciola. 2021. Effects of supplemental source of magnesium and inclusion of buffer on ruminal microbial fermentation in continuous-culture. J. Dairy Sci. 104:7820-7829. https://doi.org/10.3168/jds.2020 $-20020$.

Bach, A., I. Guasch, G. Elcoso, J. Duclos, and H. Khelil-Arfa. 2018. Modulation of rumen $\mathrm{pH}$ by sodium bicarbonate and a blend of different sources of magnesium oxide in lactating dairy cows submitted to a concentrate challenge. J. Dairy Sci. 101:9777-9788. https://doi.org/10.3168/jds.2017-14353.

Bach, A., and M. D. Stern. 1999. Effects of different levels of methionine and ruminally undegradable protein on the amino acid profile of effluent from continuous culture fermenters. J. Anim. Sci. 77:3377-3384. https://doi.org/10.2527/1999.77123377x.

Beede, D. 2017. Can we differentiate supplemental magnesium sources nutritionally? Pages $99-107$ in 26th Tri-State Dairy Nutrition Conference, Fort Wayne, IN. M. L. Eastridge, ed. Ohio State University.

Bernard, J. K., J. W. West, N. Mullis, Z. Wu, and S. J. Taylor. 2014 Evaluation of calcareous marine algae supplements on production and metabolic parameters of early lactation dairy cows. Prof. Anim. Sci. 30:649-656. https://doi.org/10.15232/pas.2014-01339.

Brandao, V. L. N., and A. P. Faciola. 2019. Unveiling the relationships between diet composition and fermentation parameters response in dual-flow continuous culture system: A meta-analytical approach. Transl. Anim. Sci. 3:1064-1075. https://doi.org/10.1093/ tas/txz019.

Brandao, V. L. N., M. I. Marcondes, and A. P. Faciola. 2020. Comparison of microbial fermentation data from dual-flow continuous culture system and omasal sampling technique: A meta-analytical approach. J. Dairy Sci. 103:2347-2362. https://doi.org/10.3168/ jds.2019-17107.

Broderick, G. A., and J. H. Kang. 1980. Automated simultaneous determination of ammonia and total amino acids in ruminal fluid and in vitro media. J. Dairy Sci. 63:64-75. https://doi.org/10 .3168/jds.S0022-0302(80)82888-8.

Calsamiglia, S., M. D. Stern, and J. L. Firkins. 1996. Comparison of nitrogen-15 and purines as microbial markers in continuous culture. J. Anim. Sci. 74:1375-1381. https://doi.org/10.2527/1996 $.7461375 \mathrm{x}$.

Chiou, W. L. 1978. Critical evaluation of the potential error in pharmacokinetic studies of using the linear trapezoidal rule method for the calculation of the area under the plasma level-time curve. J. Pharmacokinet. Biopharm. 6:539-546. https://doi.org/10.1007/ BF01062108.

Cruywagen, C. W., S. Taylor, M. M. Beya, and T. Calitz. 2015. The effect of buffering dairy cow diets with limestone, calcareous marine algae, or sodium bicarbonate on ruminal $\mathrm{pH}$ profiles, production responses, and rumen fermentation. J. Dairy Sci. 98:5506-5514. https://doi.org/10.3168/jds.2014-8875.

Dehority, B. A., R. R. Johnson, O. G. Bentley, and A. A. Moxon. 1958. Studies on the metabolism of valine, proline, leucine and isoleucine by rumen microorganisms in vitro. Arch. Biochem. Biophys. 78:15-27. https://doi.org/10.1016/0003-9861(58)90310-2.

Erdman, R. A., R. L. Botts, R. W. Hemken, and L. S. Bull. 1980. Effect of dietary sodium bicarbonate and magnesium oxide on production and physiology in early lactation. J. Dairy Sci. 63:923-930. https://doi.org/10.3168/jds.S0022-0302(80)83027-X.

Erdman, R. A., R. W. Hemken, and L. S. Bull. 1982. Dietary sodium bicarbonate and magnesium oxide for early postpartum lactating dairy cows: Effects of production, acid-based metabolism, and digestion. J. Dairy Sci. 65:712-731. https://doi.org/10.3168/jds .S0022-0302(82)82259-5.

Goff, J. P. 2018. Invited review: Mineral absorption mechanisms, mineral interactions that affect acid-base and antioxidant status, and diet considerations to improve mineral status. J. Dairy Sci. 101:2763-2813. https://doi.org/10.3168/jds.2017-13112.

Hoover, W. H., B. A. Crooker, and C. J. Sniffen. 1976. Effects of differential solid-liquid removal rates on protozoa numbers in continuous cultures of rumen contents. J. Anim. Sci. 43:528-534.

Hu, W., and M. R. Murphy. 2005. Statistical evaluation of early- and mid-lactation dairy cow responses to dietary sodium bicarbonate addition. Anim. Feed Sci. Technol. 119:43-54. https://doi.org/10 .1016/j.anifeedsci.2004.12.005.

Krause, K. M., and G. R. Oetzel. 2006. Understanding and preventing subacute ruminal acidosis in dairy herds: A review. Anim. Feed Sci. Technol. 126:215-236. https://doi.org/10.1016/j.anifeedsci 2005.08.004.

Krizsan, S. J., S. Ahvenjärvi, H. Volden, and G. A. Broderick. 2010. Estimation of rumen outflow in dairy cows fed grass silage-based diets by use of reticular sampling as an alternative to sampling from the omasal canal. J. Dairy Sci. 93:1138-1147. https://doi .org/10.3168/jds.2009-2661.

Lana, R. P., J. B. Russell, and M. E. Van Amburgh. 1998. The role of $\mathrm{pH}$ in regulating ruminai methane and ammonia production. J. Anim. Sci. 76:2190-2196. https://doi.org/10.2527/1998.7682190x.

Leno, B. M., S. E. LaCount, C. M. Ryan, D. Briggs, M. Crombie, and T. R. Overton. 2017. The effect of source of supplemental dietary calcium and magnesium in the peripartum period, and level of dietary magnesium postpartum, on mineral status, performance, and energy metabolites in multiparous Holstein cows. J. Dairy Sci. 100:7183-7197. https://doi.org/10.3168/jds.2017-12773.

May, M. L., M. J. Quinn, N. DiLorenzo, D. R. Smith, K. E. Hales, D. D. Simms, and M. L. Galyean. 2009. Effects of adding MIN-AD to steam-flaked corn-based diets with or without wet corn distillers grain plus solubles on performance by beef cattle during receiving and finishing phases. Prof. Anim. Sci. 25:559-568. https://doi.org/ 10.15232/S1080-7446(15)30758-0.

Mertens, D. R., M. S. Allen, J. Carmany, J. Clegg, A. Davidowicz, M. Drouches, K. Frank, D. Gambin, M. Garkie, B. Gildemeister, D. Jeffress, C. S. Jeon, D. Jones, D. Kaplan, G. N. Kim, S. Kobata, D. Main, X. Moua, B. Paul, J. Robertson, D. Taysom, N. Thiex, J. Williams, and M. Wolf. 2002. Gravimetric determination of amylase-treated neutral detergent fiber in feeds with refluxing in beakers or crucibles: Collaborative study. J. AOAC Int. 85:1217-1240.

Neville, E. W., A. G. Fahey, V. P. Gath, B. P. Molloy, S. J. Taylor, and F. J. Mulligan. 2019. The effect of calcareous marine algae, with or without marine magnesium oxide, and sodium bicarbonate on rumen $\mathrm{pH}$ and milk production in mid-lactation dairy cows. J. Dairy Sci. 102:8027-8039. https://doi.org/10.3168/jds.2019-16244.

NRC. 2001. Nutrient Requirements of Dairy Cattle. National Academies Press.

Owens, F. N., D. S. Secrist, W. J. Hill, and D. R. Gill. 1998. Acidosis in cattle: A review. J. Anim. Sci. 76:275-286. https://doi.org/10 $.2527 / 1998.761275 x$.

Rogers, J. A., C. L. Davis, and J. H. Clark. 1982. Alteration of rumen fermentation, milk fat synthesis, and nutrient utilization with mineral salts in dairy cows. J. Dairy Sci. 65:577-586. https://doi .org/10.3168/jds.S0022-0302(82)82235-2.

Ruiz-Moreno, M., E. Binversie, S. W. Fessenden, and M. D. Stern. 2015. Mitigation of in vitro hydrogen sulfide production using bismuth subsalicylate with and without monensin in beef feedlot diets. J. Anim. Sci. 93:5346-5354. https://doi.org/10.2527/jas.2015 $-9392$.

Soder, K. J., A. F. Brito, and M. D. Rubano. 2013. Effect of supplementing orchardgrass herbage with a total mixed ration or flaxseed on fermentation profile and bacterial protein synthesis in continuous culture. J. Dairy Sci. 96:3228-3237. https://doi.org/10 .3168/jds.2012-6307.

Teh, T. H., R. W. Hemken, and R. J. Harmon. 1985. Dietary magnesium oxide interactions with sodium bicarbonate on cows in early lactation. J. Dairy Sci. 68:881-890. https://doi.org/10.3168/jds .S0022-0302(85)80905-X. 
Thomas, J. W., and R. S. Emery. 1969. Additive nature of sodium bicarbonate and magnesium oxide on milk fat concentrations of milking cows fed restricted-roughage rations. J. Dairy Sci. 52:17621769. https://doi.org/10.3168/jds.S0022-0302(69)86838-4.

Van Soest, P. J. 1994. Nutritional Ecology of the Ruminant. 2nd ed. Cornell Univ. Press.

Weller, R. A., and A. F. Pilgrim. 1974. Passage of protozoa and volatile fatty acids from the rumen of the sheep and from a continuous in vitro fermentation system. Br. J. Nutr. 32:341-351. https://doi .org/10.1079/BJN19740087.

Zyzak, W., F. Brzóska, B. Brzóska, and J. Michalec-Dobija. 2002. The solubility and availability of magnesium from calcium-magnesium carbonate and magnesium carbonate. J. Anim. Feed Sci. 11:695707. https://doi.org/10.22358/jafs/67927/2002.

\section{ORCIDS}

B. C. Agustinho $\odot$ https://orcid.org/0000-0001-5917-234X

A. Ravelo () https://orcid.org/0000-0002-6583-4271

J. R. Vinyard () https://orcid.org/0000-0002-4107-9830

R. R. Lobo $\odot$ https://orcid.org/0000-0003-1883-6212

J. A. Arce-Cordero (ㄴ https://orcid.org/0000-0003-2111-5993

H. F. Monteiro @ https://orcid.org/0000-0003-3305-4497

S. Bennett @ https://orcid.org/0000-0001-8025-9044

E. R. Q. Vieira ๑ https://orcid.org/0000-0003-0375-410X

C. Stoffel $\odot$ https://orcid.org/0000-0003-2572-3320

A. P. Faciola @ https://orcid.org/0000-0003-0935-6233 